\title{
Academic-Service Partnerships in Nursing: An Integrative Review
}

\author{
Judy A. Beal \\ School of Nursing and Health Sciences, Simmons College, Boston, MA 02115, USA \\ Correspondence should be addressed to Judy A. Beal, judy.beal@simmons.edu \\ Received 5 September 2011; Revised 31 December 2011; Accepted 9 January 2012 \\ Academic Editor: Marita G. Titler \\ Copyright ( 2012 Judy A. Beal. This is an open access article distributed under the Creative Commons Attribution License, which \\ permits unrestricted use, distribution, and reproduction in any medium, provided the original work is properly cited. \\ This integrative review summarizes currently available evidence on academic-service partnerships in the profession of nursing. \\ More than 300 articles, published primarily in refereed journals, were accessed. Articles (110) were included in this review as \\ they presented detailed and substantive information about any aspect of a nursing academic-service partnership. The majority \\ were anecdotal in nature. Topics clustered around the following categories: pre-requisites for successful partnerships, benefits of \\ partnerships, types of partnerships, and workforce development with its themes of academic-practice progression and educational \\ re-design. Many examples of partnerships between academic and service settings were thoroughly described and best practices \\ suggested, most often, however, without formal evaluation of outcomes. Nursing leaders in both settings have a long tradition of \\ partnering with very little replicable evidence to support their efforts. It is critical that future initiatives evaluate the effectiveness of \\ these partnerships, not only to ensure quality of patient outcomes but also to maximize efforts at building capacity for tomorrow's \\ workforce.
}

\section{Introduction}

In November 2010, the Institute of Medicine (IOM) released its highly anticipated Report on the Future of Nursing [1]. This report called for major initiatives to redesign both nursing education and practice to better prepare nurses to lead during health care reform and beyond. In particular, the report outlined the need for increasing baccalaureate prepared nurses to $80 \%$ of the workforce, doubling the number of doctorally prepared faculty, removing scope of practice barriers, and disseminating successful collaborative improvement initiatives. Additionally, it recommended implementing nurse residency programs, ensuring that all nurses engage in lifelong learning, preparing and enabling nurses to lead change to advance health, and building an infrastructure for the collection and analysis of interprofessional health care workforce data [1]. It is clear that if we are to achieve these goals, academic and practice leaders must work together. Nurse leaders from both academic and service settings have a long history of collaborating [2-4], but now must do so more effectively and with greater sense of urgency than ever before [5].

A partnership is defined as an arrangement where parties agree to cooperate to advance their mutual interests [6]. In the profession of nursing, academic-service partnerships are most often defined as strategic relationships between educational and clinical practice settings that are established to advance their mutual interests related to practice, education, and research [7]. Although these alliances may be formally arranged, they are more typically informal in nature. More formal and structured relationships have been found to demonstrate greater levels of innovation and effectiveness [8].

Ironically, the twentieth century transition from hospital based training to academically-based nursing education contributed inadvertently but substantially to the development of a wide chasm between academic and service sectors [9]. The melding of nursing education and service dates back to the 17 th century when the education of nurses was most often conducted in concert with religious traditions and communities [4]. Partnerships with physicians, medical colleges, and hospitals were the cornerstone of 18th and 19th century nursing education. While contemporary leaders have repeatedly advocated for nursing educators and clinicians to forge new collaborative bonds $[2,3,5,7,10-13]$, the salience of their call has taken on new urgency in the wake of national health care reform's priorities of affordable quality care and provider accountability. The purpose of this 
integrative review of the existing literature on academicservice partnerships in nursing is to provide a foundation for future knowledge development by describing what is currently known about these ventures, and offering an agenda of priorities for moving forward.

\section{Methods and Materials}

An extensive review of the literature was conducted to synthesize current knowledge about academic-service partnerships in nursing. No other published report on this topic was found. The review included both empirical and conceptual articles published from 1990 through 2010. Data collection consisted of a search of the Cochrane Library, CINAHL, and MEDLINE databases using the following keywords: nursing, nursing education partnerships, academic-service partnerships, academic-practice partnerships, and nursing education redesign. Consistent with the methodological approach [14], references were also located through journal hand searching and the use of reference lists in retrieved articles. More than 300 articles, published primarily in refereed journals, were accessed. Eligibility criteria for inclusion in the review were English language; publication within the last twenty years; detailed and substantive information about any aspect of a nursing academic-service partnership.

\section{Results}

More than 300 citations were accessed. Of these, 110 met the criteria for inclusion, only nine of which reported on original research. Many examples of partnerships between academic and service settings were thoroughly described and best practices suggested, but most lacked formal evaluation of outcomes. An analysis of the main issues discussed in these articles clustered around the following categories: prerequisites for successful partnerships, benefits of partnerships, types of partnership, and workforce development with its themes of academic-practice progression and educational redesign. Key points in each of these categories are described below.

3.1. Pre-Requisites for Successful Partnerships. Many authors not only called for a recommitment to partnering but also identified key pre-requisites to developing and sustaining effective academic-service partnerships [15-34]. They acknowledged that the process of establishing such collaborative relationships can be both difficult and time consuming despite its rewards. Successful partnerships always start with self- and mutual-assessments of strengths and opportunities. From the very beginning, it is essential that each partner bring something valuable to the partnership [15-19]. Key elements of an effective partnership always included mutual trust; shared vision, commitment, and goals; mutual respect; recognition of opportunities and strengths; open and ongoing communication [20-27]. Specific strategies for developing and sustaining partnerships were written, formalized, and measureable goals and ongoing evaluation; strongly articulated institutional leadership support; the ability to take risks and tolerate ambiguity; structured accountability; institutionally shared resources; dedicated time; celebration of successes. While all of the articles reviewed either implied or explicitly stated the difficulties inherent in the process, all reported that if these key elements were in place, success and satisfaction were more likely, leading to sustainability of the partnership.

3.2. Benefits of Partnerships. According to Bleich et al. [3], who are considered thought leaders on the topic of academicservice partnerships in nursing, the benefits that were cited by the American Association of Colleges of Nursing (AACN) in 1990 [7] remain true today. These include strength and power in mutual goal setting, increased visibility and esteem for nursing's contribution to health care delivery, maximization of resources, enhanced opportunity for educators to remain current in practice, cost effective quality care and education of students and staff, increased research productivity, and development of patterns of excellence [7]. Other benefits of academic-service partnerships cited in the literature included improving organizational efficiencies, providing greater opportunities for innovations and new ways of thinking and doing $[35,36]$, and enhanced recruitment and retention [37].

3.3. Types of Partnerships. Academic-service partnerships have been widely discussed in the literature. These include partnerships with hospitals, community health, and public health agencies, nursing homes, schools, and governmental agencies. From early on in nursing's history, the focus of these partnerships was directed toward providing care to specific populations, educating students and staff, producing research, and addressing workforce issues in nursing. Faculty practice models and centers for research are two examples of partnerships that developed in the mid-20th century. Today, in the early 21 st century, the majority of academic-service partnerships are focused on building workforce capacity.

3.3.1. Models of Faculty Practice. Faculty practice models, first seen in the United States in the 1950s [3, 38], emerged as innovative approaches to care for vulnerable populations, support training of advanced practice nurses, build a more educated workforce infrastructure, and advance nursing research $[3,12,13,15]$.

One model of faculty practice was the academic nursing center, housed in the university and staffed by faculty. These centers provided cost-effective care to their neighboring communities $[2,39,40]$. While key challenges were mostly financial, or related to legal and regulatory issues [41], patient outcomes were consistently excellent [42].

While faculty practice had its early roots in academic nursing centers, other popular models allowed for joint appointments for both faculty in a practice setting and the practitioners in the university. In a critical review of 35 articles, Sawyer and colleagues [43] concluded that, by 2000, faculty practice had become an integral component of faculty role expectations at most schools of nursing. Successful faculty practice models are well described in the literature 
[44-67]. Authors consistently attributed this success to building a strong infrastructure to support the practice initiative, including administrative support for business, legal, and regulatory oversight $[51,55,57,60,66]$. Equally important were trust among partners [57], and a shared and well-articulated mission and vision [54, 55, 58, 60, 61].

The many benefits to faculty practice for all partners, regardless of model employed, included cost effectiveness, good patient outcomes, positive student learning, increased research productivity, and faculty satisfaction [49-64]. Additional benefits to the practice site were opportunities for staff to work with highly knowledgeable and engaged faculty members, and ability to recruit new graduates [63]. The communities served also benefited from the many practice innovations that were generated from the synergies developed between faculty, students, and providers [60]. Today, faculty practice models continue to provide opportunities for nurse practitioner faculty to maintain certification which is critical to accreditation of nurse practitioner academic programs [68].

3.3.2. Centers for Research and Evidence Based Practice. While academic nursing centers and collaborative faculty practice collaborations were typically developed to provide patient care and student learning experiences, research collaborations between faculty and clinicians were often an unanticipated benefit. Development of partnerships for the primary purpose of advancing research and building an evidencebased practice began to emerge soon thereafter [3, 69-75]. In these partnerships, faculty has access to subjects for their research and clinicians have access to research experts and consultation. The outcomes of such partnerships included enhanced evidence-based practice, increased grant funding, and overall improvement in the "generation, dissemination, and application of knowledge for the improvement of nursing practice and patient outcomes" [70, page 114]. These research-focused partnerships have not only enhanced patient outcomes but also provided research training for a new generation of scholars.

3.4. Workforce Development Initiatives. The majority of academic-service partnerships in the past decade have focused on building professional nurse workforce capacity [76]. All of the recent workforce predictions point to a serious nursing shortage. The Robert Wood Johnson Foundation's 2010 report, for example, forecasts a deficit of "more than 260,000 registered nurses by 2025 unless we expand nursing education capacity quickly and dramatically" [76]. Published papers addressing this topic focused on anticipated problems associated with a nursing workforce inadequately prepared to lead and implement change, and the concomitant need for nursing education re-design. Authors proposed strategies to realign academic and service resources, with the goals of improving the quality of prelicensure education, building faculty capacity, and ensuring quality and safety of patient care. Two central themes that emerged in the literature review within this category include academic-practice progression and educational re-design.
3.4.1. Academic-Practice Progression. In 2008, the Nursing Executive Center [77, 78] published its two-volume report entitled, "Bridging the Preparation-Practice Gap." The first volume [77] of the report detailed the results of a survey of 400 nursing school directors and over 3500 hospital-based leaders on 36 competencies required of new graduates. The result indicated a need for better preparation of students on all 36 competencies. The top ten priorities for improvement included utilization of information technologies, rapport with patients and families, respect for diverse cultural perspectives, patient assessment, customer service, documentation, medication administration, patient advocacy, interdisciplinary team communication, accountability for one's actions, ability to work as a team member, and recognition of when to ask for help [77]. Importantly, the report noted polarized opposing views on practice readiness with "nearly 90 percent of academic leaders believing that their new graduate nurses are fully prepared to provide safe and effective care, compared to only 10 percent of hospital and health system executives" [78, page X]. The Board called for a more collaborative approach to close this significant gap, using strategies such as targeted clinical rotations, expert clinical instruction, and exceptional salient student experiences.

Several approaches have been described to address this gap in preparation to practice readiness. The most wellknown is the senior capstone experience where students work one-on-one with a clinical nurse to care for assigned patients $[79,80]$. Reports of other academic-service partnerships have focused on enhancing individual student experiences with vulnerable populations [75, 81-90]; with schools $[91,92]$, the elderly $[93,94]$, and in primary care settings $[95,96]$.

3.4.2. Nursing Education Re-Design. At the same time that the Nursing Executive Center published its reports, data were emerging on how faculty shortages across the country were limiting student capacity [97, 98]. A more formalized educational re-design initiative was one approach to increase faculty capacity and to more effectively match the realities of clinical practice for today and tomorrow. A 2008 white paper [98] jointly commissioned by the RWJ Foundation, the Center to Champion Nursing in America (CCNA), and the U. S. Department of Labor, Employment, and Training Administration described innovative efforts underway to address the nursing faculty shortage. Four approaches to increasing nursing education capacity were described: (1) creating strategic partnerships to align and leverage stakeholder resources; (2) increasing nursing faculty capacity and diversity; (3) re-designing nursing education; (4) flexing policy and regulation [98]. Examples of innovations within these approaches included accelerated entry level BSN programs, centralized clinical placement initiatives, accelerated doctoral programs, adjunct clinical faculty training, the Robert Wood Johnson New Careers in Nursing Program, dedicated education units, nurse residency programs, Nursing Teacher Loan Forgiveness programs, and BSN in 10 legislation [98]. 
The development of accelerated postbaccalaureate nursing education programs was an early attempt at increasing the nursing workforce. According to the AACN [99], today there are more than 281 accelerated baccalaureate and 63 accelerated master's programs. While impressive in scope, these efforts alone cannot meet the future demands for a well-prepared and adequately numbered workforce. Furthermore, these programs were not designed as academicservice partnerships, and it has become increasingly apparent that nursing must work together to address the issues of workforce capacity. Reinhard and Hassmiller [100], along with Joynt and Kimball [98], described the collaboration between the RWJ Foundation and the American Association of Retired Persons (AARP), to create the Center to Champion Nursing in America (CNAA). The main emphasis of this center is raise awareness of the nursing shortage and to highlight innovative partnerships that are working to resolve this crisis. Between 2009 and 2010, the CNAA at AARP, the RWJ Foundation, the U.S. Department of Labor's Employment and Training Administration, and the U.S. Department of Health and Human Services' Health Resources and Services Administration (HRSA) cosponsored two national summits on nursing education capacity. Exemplars presented at these summits included public and private partnerships designed to prepare the future nursing workforce [76, 101]. Many of these are state-wide initiatives modeled after the Oregon Consortium for Nursing Education (OCNE). This consortium has completely redesigned the nursing curriculum and standardized nursing education in eight of the 15 community college nursing programs and the multicampus Oregon Health and Science University (OHSU) School of Nursing $[17,101,102]$. Other states with robust collaborations between public and private schools of nursing and their practice partners include California, Florida, New Jersey, Hawaii, Massachusetts, Michigan, Mississippi, New York, North Carolina Texas, and Virginia [76, 101]. Reported innovations include: analyses of the preparation-practice gap, seamless admissions and curricula, use of standardized patients, technology and simulation, the development of competencies for the nurse of the future, regional collaborations, retention strategies, centralized clinical placement systems, and faculty development initiatives.

Some of this educational re-design work was developed as a result of AACN's 2003 support to establish the University Health System Consortium [103]. The consortium's purpose was to address the need to ensure a more educated workforce and a more effective transition into the professional role for baccalaureate graduates. Nurse executives and deans from hospitals and schools of nursing in academic health science centers in California, Iowa, Kentucky, Oregon, Tennessee, and Texas formed a joint task force that identified goals around the recruitment, retention, and expansion of baccalaureate students, successful transition through structured residency programs, and a professional and healthy work environment with differential salaries based on academic preparation.

MacIntyre and colleagues [104] recommended five strategies to realign scarce resources of faculty and clinical placements with the goals of improving the quality of prelicensure education, building faculty capacity, and ensuring quality and safety of patient care. They argued (1) that faculty and practice leaders must reconceptualize nursing student and staff relationships as well as the role of faculty by encouraging experienced staff nurses to become more involved in the education of students. (2) Experienced faculty members from the university could then become mentors to novice staff educators who in turn may become excited about pursuing the faculty role. Furthermore, they recommended (3) that schools of nursing develop resources to prepare the novice educators for the teaching role. They encouraged faculty (4) to think about alternative clinical sites and experiences with their practice partners and (5) to build the evidence-based content of the curriculum. As changes such as these require full partnership, they must be based on a sound methodological approach and transparency [105]. If effective, MacIntyre and colleagues [104] concluded that such an approach would increase workforce capacity.

Dedicated education units (DEU) were designed as partnerships and resonate with the suggestions made by MacIntyre and colleagues. One of the first articles to describe the DEU came from Flinders University in Australia and was published in 1999 [106]. A dedicated education unit is a "partnership of nurse executives, staff nurses, and faculty who transform patient units into environments of support for nursing students and staff nurses while continuing the critical work of providing care..." [107, page 31]. The DEU model employs well-prepared RN clinicians as educators for nursing students. Academic faculty serve as role models and mentors to these scholar clinicians. While a number of models have been described [106-112], only a few studies have been published to date evaluating outcomes of this recent innovation [106, 108, 111, 112]. Of these, all concluded that the dedicated education increased educational capacity as well as student and staff satisfaction, and was a good source for clinical placements.

The development of the clinical nurse leader $(\mathrm{CNL})$ role and supporting curriculum is another recent example of academic-service partnership that addresses the preparationpractice gap. The AACN proposed the CNL role in 2003 after consulting with an extensive group of leaders from a variety of settings across the healthcare delivery system. The CNL is a provider and a manager of care at the point of care to individuals and cohorts [113]. The master's level curriculum is based on values and core competencies identified by the Nursing Executive Center [97, 98]. The curriculum also addresses concerns voiced by the Institute of Medicine [114, 115] regarding the fragmentation of healthcare delivery that contributes significantly to the high error rate and decreased quality in patient care. Starting in 2004, 77 academic-practice partners began piloting several CNL demonstration projects. Today, there are more than 108 academic partners and 210 practice partners, a CNL certification examination, and hundreds of CNL graduates across the country. The Department of Veterans Affairs has committed to implementing the CNL role in all VA medical centers by 2016 [116]. 
TABLE 1: Suggested outcome measures of effective partnerships.

Outcome measures for effective academic-service partnerships at the individual partner level
Expected outcomes

The number of quality clinical placements will increase and diversify

The number of qualified clinical faculty recruited from clinical partnership sites will increase

The opportunities for shared experiences (research, practice projects, shared teaching, DEUs, etc.) between faculty and clinical staff will increase

The number of students enrolled will increase along with the quality of students accepted

Academic progression policies will support excellence

Student retention will be increased

Student performance on NCLEX-RN will increase

Student employment rates post graduation will increase

Orientation time for new graduates will decrease

Recruitment and orientation costs to service organizations will decrease

Retention rates for new graduates will increase

Patient safety and quality indicators of success will increase

The percentage of nurses who return for advanced degrees will increase

Research Productivity will increase

The percentage of nurses who become leaders within their institutions and beyond will increase

The percentage of nurses who become politically active will increase

Satisfaction of students, staff, faculty, and employers will increase

Outcome measures for effective academic-service partnerships at the regional level

Outcome measures for effective academic-service partnerships at the individual level
The numbers of regional action coalitions will increase and results of their work will be disseminated nationally

The AACN-AONE task force on academic-practice partnerships will take a national role in promoting a national level discussion of and implementation plan on best practices and implementation strategies
As is typical with the development of CNL programs, nursing leaders from three New Jersey healthcare organizations partnered with the College of New Jersey to develop their curriculum. They worked together to implement the program with representatives from both practice and the academic settings involved in teaching the students [117]. A focus on clinical relevance was a key element in the curriculum which addressed prior concerns about the preparationpractice gap $[97,98]$.

Smith and Dabbs [118] published one of the few studies to include patient outcomes in their formative and summative evaluation methodology to assess outcomes of a precursor to the CNL model on a 46-bed medical-surgical unit. A year after implementation, falls with injury were decreased by $67 \%$ and pressure ulcer rates decreased to $0 \%$. Patient satisfaction increased and staff turnover decreased. The average length of stay decreased from 4.22 to 3.45 days on the pilot unit and patient satisfaction with discharge planning improved.

\section{Discussion and Conclusions}

While the literature is replete with descriptions of numerous academic-service partnerships that have developed over the past twenty years, objective evidence for the success of these relationships is limited at best. While much informal evaluation has occurred, very few of the innovations described have been formally studied. Generalizability of research published to date is limited by small, nonrepresentative samples in single locations followed over relatively short time periods.

As academic and service partners move forward to design and implement changes to prepare the next generation of professional nurses for the realities of a changing healthcare delivery landscape, both process and outcome evaluations must be incorporated in the planning. Both research and quality improvement methodologies may be useful, depending on the proposed innovation. The key point is that measurement is essential to determine the short- and longterm effectiveness and the efficiency of these initiatives. We will need to know, for example, the kind and number of staff and faculty resources required to ensure success, and their associated costs. The effect on patient outcomes must also be considered, as well as staff and faculty outcomes, such as readiness for practice and effects on workloads, job satisfaction, recruitment, and retention. Table 1 outlines a more comprehensive list of suggested outcomes to measure partnership success.

Despite the limitations of the extant literature, this integrative review has highlighted a number of successful 
or promising academic-service partnerships and associated benefits perceived by the innovators. Thought leaders have also described the prerequisites that should frame future partnerships. The IOM's call [1] is urgent and compelling. Nursing leaders are stepping up to the plate on the local, regional, and national levels to respond to the inherent challenges. Schools of Nursing and their practice partners continue to develop new approaches to solve the problems of the lack of clinical faculty and clinical placements, as well as the nursing shortage. States and regions are responding to the call from the RWJ Foundation to establish Regional Action Coalitions. Leaders from the AACN, the American Organization of Nurse Executives, and the Association of State and Territorial Directors of Public Health Nursing have partnered to form a national task force to identify best practices in academic-service partnerships. The nursing profession eagerly awaits the results from these impressive partnership activities. The time is right to move forward by building together on past successes for both the good of our patients and the continuing development of our professional capacity.

\section{Conflict of Interests}

The author declares no actual or potential conflict of interest.

\section{Acknowledgment}

This work was partially funded by the Robert Wood Johnson Executive Nurse Fellows Program, Simmons College, and the University of Texas Health Sciences Center School of Nursing.

\section{References}

[1] Institute of Medicine, The Future of Nursing-Leading Change, Advancing Health, National Academies of Health, Washigton, DC, USA, 2011.

[2] S. E. Barger, "Establishing a nursing center: learning from the literature and the experiences of others," Journal of Professional Nursing, vol. 11, no. 4, pp. 203-212, 1995.

[3] M. R. Bleich, P. O. Hewlett, K. L. Miller, and K. Bender, "Beyond tradition: synergizing intellectual and material capital to forge the new academic-service partnership," Journal of Professional Nursing, vol. 20, no. 5, pp. 285-294, 2004.

[4] M. Libster, "Lessons learned from a history of perseverance in education-practice partnerships," Journal of Professional Nursing, vol. 27, no. 6, pp. e76-e81, 2011.

[5] E. O'Neill, Leadership Lab Book-A Discovery Guide for Working across Organizational Boundaries in Health Care, Center for the Health Professions, UCSF, San Francisco, Calif, USA, 2011.

[6] http://en.wikipedia.org/wiki/Partnership.

[7] American Association of Colleges of Nursing, Resolution: need for Collaborative Relationships Between Nursing Education and Practice, AACN, Washigton, DC, USA, 1990.

[8] Institute of Medicine, Future of the Public's Health in the 21st Century, National Academies of Health, Washigton, DC, USA, 2003.
[9] M. R. Keefe, J. D. Leuner, and M. A. Laken, "Integrating: research, practice, and education," Nursing and Health Care Perspectives, vol. 21, no. 6, pp. 287-292, 2000.

[10] Pew Health Profession Commission, Recreating Health Professional Practice for a New Century, Pew Health Professions Commission, San Francisco, Calif, USA, 1998.

[11] S. E. Barger, "Partnerships for practice-a necessity in the new millennium," Journal of Professional Nursing, vol. 15, no. 4, p. 208, 1999.

[12] H. P. O’Neill and M. R. Bleich, “The re-emergence of academic-service partnerships: responses to the nursing shortage, work environment issues, and beyond," Journal of Professional Nursing, vol. 20, no. 5, pp. 273-274, 2004.

[13] M. F. Fralic, "Hardwiring the "Three-legged stool": nursing's vital education/practice/research triad," Journal of Professional Nursing, vol. 20, no. 5, pp. 281-284, 2004.

[14] R. Whittemore and K. Knafl, "The integrative review: updated methodology," Journal of Advanced Nursing, vol. 52, no. 5, pp. 546-553, 2005.

[15] S. T. Hegyvary, "Academic-corporate partnership to improve long-term care," Nursing Homes, vol. 40, pp. 40-45, 1991.

[16] T. Shellenbarger, "Professional-community partnership: successful collaboration," Annual Review of Nursing Education, vol. 1, pp. 43-58, 2003.

[17] T. A. Harvath, M. Flaherty-Robb, D. L. White, K. A. Talerico, and C. Hayden, "Best practices initiative: nurturing partnerships that promote change," Journal of Gerontological Nursing, vol. 33, no. 11, pp. 19-26, 2007.

[18] E. O’Neil and P. Krauel, “Building transformational partnerships in nursing," Journal of Professional Nursing, vol. 20, no. 5, pp. 295-299, 2004.

[19] C. L. Williams-Barnard, B. Bockenhauer, V. O. Domaleski, and J. A. Eaton, "Professional learning partnerships: a collaboration between education and service," Journal of Professional Nursing, vol. 22, no. 6, pp. 347-354, 2006.

[20] A. McNamara, "Mind the gap: transitions in nursing education and care delivery systems," Nursing Administration Quarterly, vol. 25, no. 1, pp. 39-50, 2000.

[21] D. Gaskill, P. Morrison, F. Sanders et al., "University and industry partnerships: lessons from collaborative research," International Journal of Nursing Practice, vol. 9, no. 6, pp. 347-355, 2003.

[22] E. L. Smith and M. C. Tonges, "The Carolina nursing experience: a service perspective on an academic-service partnership," Journal of Professional Nursing, vol. 20, no. 5, pp. 305-309, 2004.

[23] M. MacPhee, "Developing a practice-academic partnership logic model," Nursing Outlook, vol. 57, no. 3, pp. 143-147, 2009.

[24] K. Burke, S. Moscato, and J. Warner, "A primer on the politics of partnership between education and regulation," Journal of Professional Nursing, vol. 25, no. 6, pp. 349-351, 2009.

[25] S. E. Das E. Barger, "Building transformational partnerships in nursing," Journal of Professional Nursing, vol. 20, no. 5, pp. 295-299, 2004.

[26] L. M. Caldwell, G. Luke, and L. M. Tenofsky, "Creating valueadded linkages through creative programming: a partnership for nursing education," Journal of Continuing Education in Nursing, vol. 38, no. 1, pp. 31-36, 2007.

[27] J. M. Kirschling and J. I. Erickson, "The STTI practiceacademe innovative collaboration award: honoring innovation, partnership, and excellence," Journal of Nursing Scholarship, vol. 42, no. 3, pp. 286-294, 2010. 
[28] S. Siefer, J. Sebastian, D. Cora-Bramble, and R. Hart, "Interdisciplinary collaboration in service-learning: lessons from the health professions," Michigan Journal of Community Service Learning, vol. 3, no. 1, pp. 113-127, 1996.

[29] M. K. Engelke, M. A. Rose, D. J. Drake, and D. Marshburn, "Building and sustaining the bariatric nursing consortium," Bariatric Nursing and Surgical Patient Care, vol. 2, no. 4, pp. 285-290, 2007.

[30] D. Brown, J. White, and L. Leibbrandt, "Collaborative partnerships for nursing faculties and health service providers: what can nursing learn from business literature?" Journal of Nursing Management, vol. 14, no. 3, pp. 170-179, 2006.

[31] C. L. Gilliss and M. A. Fuchs, "Guest Editorial: reconnecting education and service: partnering for success," Nursing Outlook, vol. 55, no. 2, pp. 61-62, 2007.

[32] R. S. Kaplan, D. P. Norton, and B. Rugelsjoen, "Managing alliances with the balanced scorecard," Harvard Business Review, vol. 88, no. 1-2, pp. 114-121, 2010.

[33] S. K. Donaldson and M. F. Fralic, "Forging today's practiceacademic link: a new era for nursing leadership," Nursing Administration Quarterly, vol. 25, no. 1, pp. 95-101, 2000.

[34] D. Herrin, D. Hathaway, S. Jacob et al., "A model academicpractice partnership," Journal of Nursing Administration, vol. 36, no. 12, pp. 547-550, 2006.

[35] L. Clark, "Partners in practice," Nursing Management, vol. 15, no. 3, pp. 12-13, 2008.

[36] J. R. Warner and D. A. Burton, "The policy and politics of emerging academic-service partnerships," Journal of Professional Nursing, vol. 25, no. 6, pp. 329-334, 2009.

[37] S. L. Campbell, M. Prater, C. Schwartz, and N. Ridenour, "Building an empowering academic and practice partnership model," Nursing Administration Quarterly, vol. 26, no. 1, pp. 35-44, 2001.

[38] L. R. Cronenwett, "A present-day academic perspective on the Carolina nursing experience: building on the past, shaping the future," Journal of Professional Nursing, vol. 20, no. 5, pp. 300-304, 2004.

[39] S. E. Barger and W. C. Bridges, "An assessment of academic nursing centers," Nurse Educator, vol. 15, no. 2, pp. 31-36, 1990.

[40] J. H. Boettcher, "Nurse practice centers in academia: an emerging subsystem," The Journal of Nursing Education, vol. 35, no. 2, pp. 63-68, 1996.

[41] M. Oros, M. Johnatgen, S. Antol, B. R. Heller, and P. Ravella, "Community based nursing centers: challenges and opportunities in implementation and sustainability," Policy, Politics, and Nursing Practice, vol. 2, no. 4, pp. 277-287, 2001.

[42] L. Anderko and M. Uscian, "Quality outcome measures at an academic rural nurse managed center-a core safety net provider," Policy, Politics, and Nursing Practice, vol. 4, no. 2, pp. 288-294, 2001.

[43] M. J. Sawyer, I. M. Alexander, L. Gordon, L. J. Juszczak, and C. Gilliss, "A critical review of current nursing faculty practice," Journal of the American Academy of Nurse Practitioners, vol. 12, no. 12, pp. 511-516, 2000.

[44] J. M. Beitz and M. M. Heinzer, "Faculty practice in joint appointments: implications for nursing staff development," Journal of Continuing Education in Nursing, vol. 31, no. 5, pp. 232-237, 2000.

[45] W. Bonnel, J. Belt, D. Hill, S. Wiggins, and R. Ohm, "Challenges and strategies for initiating a nursing facility practice," Journal of the American Academy of Nurse Practitioners, vol. 12, no. 9, pp. 353-359, 2000.
[46] M. A. DiMarco, "Faculty practice at a homeless shelter for women and children," Holistic Nursing Practice, vol. 14, no. 2, pp. 29-37, 2000.

[47] J. S. Krothe, B. Flynn, D. Ray, and S. Goodwin, "Community development through faculty practice in a rural nursemanaged clinic," Public Health Nursing, vol. 17, no. 4, pp. 264-272, 2000.

[48] K. A. Ward, "Faculty clinical practice: strategies for implementation and evaluation," Nursing Forum, vol. 36, no. 4, pp. 15-20, 2001.

[49] B. A. Pilon, "Vanderbuilt school of nursing faculty practice program," Nursing Administration Quarterly, vol. 26, no. 1, pp. 14-16, 2001.

[50] M. A. Brown, "Academic faculty practice: enrichment through synergism," Applied Nursing Research, vol. 14, no. 1, pp. 56-61, 2001.

[51] B. A. Swan and L. K. Evans, "Infrastructure to support academic nursing practice," Nursing Economics, vol. 19, no. 2, pp. 68-71, 2001.

[52] H. J. Speziale, "Faculty practice in a small liberal arts college," Nurse Educator, vol. 26, no. 2, pp. 84-89, 2001.

[53] K. Williams, A. K. Cobb, J. Nowak, E. W. Domian, V. Hicks, and C. Starling, "Faculty-agency partnering for improved client outcomes," The The Journal of Nursing Education, vol. 41, no. 12, pp. 531-534, 2002.

[54] J. B. Edwards, S. Oppewal, and C. L. Logan, "Nurse-managed primary care: outcomes of a faculty practice network," Journal of the American Academy of Nurse Practitioners, vol. 15, no. 12, pp. 563-569, 2003.

[55] K. Dracup, "Impact of faculty practice on an academic institution's mission and vision," Nursing Outlook, vol. 52, no. 4, pp. 174-178, 2004.

[56] J. M. Saxe, B. J. Burgel, S. Stringari-Murray et al., "What is faculty practice?” Nursing Outlook, vol. 52, no. 4, pp. 166173, 2004.

[57] L. Chafetz, G. M. Collins-Bride, and M. White, "A nursing faculty practice for the severely mentally ill: merging practice with research," Nursing Outlook, vol. 52, no. 4, pp. 209-214, 2004.

[58] J. M. Saxe, G. M. Collins-Bride, S. Stringari-Murray, P. Dennehy, and W. Holzemer, "Strategic planning for UCSF's community health nursing faculty practices," Nursing Outlook, vol. 52, no. 4, pp. 179-188, 2004.

[59] L. A. Ament, "The evolution of midwifery faculty practice: impact and outcomes of care," Nursing Outlook, vol. 52, no. 4, pp. 203-208, 2004.

[60] C. L. Gilliss, "Guest editorial: faculty practice comes of age: standing on the shoulders of giants," Nursing Outlook, vol. 52, no. 4, p. 161, 2004.

[61] C. A. Persily, "Academic nursing practice in rural West Virginia," The Journal of Nursing Education, vol. 43, no. 2, pp. 75-77, 2004.

[62] D. A. Forrester, T. O'Keefe, and S. Torres, "Professor in residence program: a nursing faculty practice," Journal of Professional Nursing, vol. 24, no. 5, pp. 275-280, 2008.

[63] P. L. Starck, G. C. Walker, and P. A. Bohannan, "Nursing faculty practice in the Houston Linkage Model: administrative and faculty perspectives," Nurse Educator, vol. 16, no. 5, pp. 23-28, 1991.

[64] D. Arthur and K. Usher, "An application of nursing faculty practice: clinical camps," Journal of Advanced Nursing, vol. 19, no. 4, pp. 680-684, 1994. 
[65] P. I. Tagg, "Establishing a college health service in a college of nursing," Journal of American College Health, vol. 44, no. 3, pp. 120-123, 1995.

[66] B. J. Gale, "Faculty practice as partnership with a community coalition," Journal of Professional Nursing, vol. 14, no. 5, pp. 267-271, 1998.

[67] D. A. Novak, "The serendipity of faculty practice: strategies for success," Nurse Educator, vol. 24, no. 1, pp. 42-44, 1999.

[68] National Organization of Nurse Practitioner Faculties, Criteria for the Evaluation of Nurse Practitioner Programs, National Organization of Nurse Practitioner Faculties, Washigton, DC, USA, 3rd edition, 2008.

[69] M. R. Bleich, "The scholarship of practice within the academic clinical enterprise," The Journal of Nursing Education, vol. 43, no. 2, pp. 51-52, 2004.

[70] M. Dreher, L. Everett, and S. M. Hartwig, "The University of Iowa nursing collaboratory: a partnership for creative education and practice," Journal of Professional Nursing, vol. 17, no. 3, pp. 114-120, 2001.

[71] S. M. Weeks, J. Marshall, and P. Burns, "Development of an evidence-based practice and research collaborative among urban hospitals," Nursing Clinics of North America, vol. 44, no. 1, pp. 27-31, 2009.

[72] S. Lundeen, E. Harper, and K. Kerfoot, "Translating nursing knowledge into practice: an uncommon partnership," Nursing Outlook, vol. 57, no. 3, pp. 173-175, 2009.

[73] B. B. Brewer, M. A. Brewer, and A. A. Schultz, "A collaborative approach to building the capacity for research and evidencebased practice in community hospitals," Nursing Clinics of North America, vol. 44, no. 1, pp. 11-25, 2009.

[74] R. F. Levin, M. J. Vetter, J. Chaya, H. Feldman, and J. Marren, "Building bridges in academic nursing and health care practice settings," Journal of Professional Nursing, vol. 23, no. 6, pp. 362-368, 2007.

[75] G. Glazer, P. R. Ponte, E. M. Stuart-Shor, and M. E. Cooley, "The power of partnership: addressing cancer health disparities through an academic-service partnership," Nursing Outlook, vol. 57, no. 3, pp. 123-131, 2009.

[76] Robert Wood Johnson Foundation, Charting Nursing's Future: Reports on Policies that can Transform Patient Care, 2010, http://rwjf.org/files/research/20100608cnf.pdf.

[77] Nursing Executive Center, Bridging the Preparation-Practice Gap. Volume I: Quantifying New Graduate Nurse Improvement Needs, The Advisory Board Company, Washigton, DC, USA, 2008.

[78] Nursing Executive Center, Bridging the Preparation-Practice Gap. Volume II: Best Practices for Accelerating Practice Readiness of Nursing Students, The Advisory Board Company, Washigton, DC, USA, 2008.

[79] D. Y. Brockopp, M. Hardin-Pierce, and J. D. Welsh, "An agency-financed capstone experience for graduating seniors," The Journal of Nursing Education, vol. 45, no. 4, pp. 137-140, 2006.

[80] T. M. Harrison, S. Stewart, K. Ball, and M. M. Bratt, "Clinical focus program: enhancing the transition of senior nursing students to independent practice," Journal of Nursing Administration, vol. 37, no. 6, pp. 311-317, 2007.

[81] S. E. Barger and R. B. Crumpton, "Public health nursing partnership: agencies and academe," Nurse Educator, vol. 16, no. 4, pp. 16-19, 1991.

[82] M. A. Lough, "An academic-community partnership: a model of service and education," Journal of Community Health Nursing, vol. 16, no. 3, pp. 137-149, 1999.
[83] A. H. Wilson, J. L. Wold, L. Spencer, and K. Pittman, "Primary health care for Hispanic children of migrant farm workers," Journal of Pediatric Health Care, vol. 14, no. 5, pp. 209-215, 2000.

[84] S. G. Jeanfreau and M. Tennyson, "Collaboration in the provision of health care to low socioeconomic people of New Orleans," Journal of Multicultural Nursing and Health, vol. 9, no. 1, pp. 27-33, 2003.

[85] S. E. Kolb, I. Gilliland, J. Deliganis, and K. L. Light, "Ministerio de Salud: development of a mission driven partnership for addressing health care disparities in a Hispanic community," Journal of Multicultural Nursing and Health, vol. 9, no. 3, pp. 6-12, 2003.

[86] S. K. Faulchald, "Using academic-community partnerships to improve health care services for underserved populations," Journal of Multicultural Nursing and Health, vol. 10, no. 1, pp. 51-56, 2004.

[87] B. R. Heller and M. R. Goldwater, “The Governor's wellmobile: Maryland's mobile primary care clinic," The Journal of Nursing Education, vol. 43, no. 2, pp. 92-94, 2004.

[88] M. Lashley, "Promoting oral health among the inner city homeless: a community-academic partnership," Nursing Clinics of North America, vol. 43, no. 3, pp. 367-379, 2008.

[89] F. Charlie, Women Care in Vancouver's Downtown Eastside, Canadian Women's Health Network, 2008.

[90] P. Riley, "Collaboration for prevention of chronic disease in Kentucky: the health education through extension leaders program," Nursing Clinics of North America, vol. 43, no. 3, pp. 329-340, 2008.

[91] S. G. McClowry, P. Galehouse, W. Hartnagle et al., "A comprehensive school-based clinic: university and community partnership," Journal of the Society of Pediatric Nurses, vol. 1, no. 1, pp. 19-26, 1996.

[92] G. J. Kreulen, P. K. Bednarz, T. Wehrwein, and J. Davis, "Clinical education partnership: a model for school district and college of nursing collaboration," The Journal of School Nursing, vol. 24, no. 6, pp. 360-369, 2008.

[93] E. S. McConnell, D. Lekan, C. Hebert, and L. Leatherwood, "Academic-practice partnerships to promote evidence-based practice in long-term care: oral hygiene care practices as an exemplar," Nursing Outlook, vol. 55, no. 2, pp. 95-105, 2007.

[94] M. D. Mezey, E. L. Mitty, and S. G. Burger, "Re-thinking teaching nursing homes: potential for improving long-term care," The Gerontologist, vol. 48, no. 1, pp. 8-15, 2008.

[95] N. K. Boccuzzi, "CAPNA: a new development to increase quality in primary care," Nursing Administration Quarterly, vol. 22, no. 4, pp. 11-19, 1998.

[96] C. B. Hughes, J. Trofino, B. L. O’Brien, J. Mack, and M. Marrinan, "Primary care parish nursing, outcomes and implications," Nursing Administration Quarterly, vol. 26, no. 1, pp. 45-59, 2001.

[97] American Association of Colleges of Nursing, Nursing Shortage Fact Sheet, 2008, http://www.aacn.nche.edu/mediarelations/fact-sheets/nursing-shortage/.

[98] J. Joynt and B. Kimball, Blowing Open the Bottleneck: Developing New Approaches to Increase Nurse Education Capacity. White Paper 2008, http://www.rwjf.org/files/ research/3335.32415.pdf.

[99] American Association of Colleges of Nursing, Fact Sheet: Accelerated Baccalaureate and Master's Degrees in Nursing, 2011, http://www.aacn.nche.edu/cnl/CNLFactSheetpdf.

[100] S. Reinhard and S. Hassmiller, "The policy and politics of emerging academic-service partnerships," Journal of Professional Nursing, vol. 25, no. 6, pp. 329-334, 2009. 
[101] L. Lewis, B. Cleary, and S. Hassmiller, "Uniting States, sharing strategies: seven-part series on nursing education capacity solutions," American Journal of Nursing, vol. 110, no. 1-7, 2010.

[102] The OregonConsortium for Nursing Education (OCNE), http://thefutureofnursing.org/resource/detail/Oregonconsortium-nursing-education-ocne/.

[103] American Association of Colleges of Nursing, Building Capacity through University Hospital and University School of Nursing Partnerships. White Paper, 2003, http://www.aacn. nche.edu/publications/white-papers/building-capacity/.

[104] R. C. MacIntyre, T. A. Murray, C. S. Teel, and J. F. Karshmer, "Five recommendations for prelicensure clinical nursing education," The Journal of Nursing Education, vol. 48, no. 8, pp. 447-453, 2009.

[105] M. Cramer, K. Duncan, M. Megel, and S. Pitkin, "Partnering with rural communities to meet the demand for a qualified nursing workforce," Nursing Outlook, vol. 57, no. 3, pp. 148157, 2009.

[106] J. Gonda, K. Wotton, K. Edgecombe, and P. Mason, "Dedicated education units: 2. An evaluation," Contemporary Nurse, vol. 8, no. 4, pp. 172-176, 1999.

[107] I. Graham, "Leading the development of nursing within a nursing development unit: the perspectives of leadership by the team leader and a professor of nursing," International Journal of Nursing Practice, vol. 9, no. 4, pp. 213-222, 2003.

[108] T. A. Murray, "Expanding educational capacity through an innovative practice-education partnership," The Journal of Nursing Education, vol. 46, no. 7, pp. 330-333, 2007.

[109] T. W. Miller, "The dedicated education unit: a practice and education partnership," Nursing Leadership Forum, vol. 9, no. 4, pp. 169-173, 2005.

[110] S. Pappas, "Improving patient safety and nurse engagement with a dedicated education unit," Nurse Leader, vol. 5, no. 3, pp. 40-43, 2007.

[111] K. Ranse and L. Grealish, "Nursing students' perceptions of learning in the clinical setting of the Dedicated Education Unit," Journal of Advanced Nursing, vol. 58, no. 2, pp. 171179, 2007.

[112] S. R. Moscato, J. Miller, K. Logsdon, S. Weinberg, and L. Chorpenning, "Dedicated education unit: an innovative clinical partner education model," Nursing Outlook, vol. 55, no. 1, pp. 31-37, 2007.

[113] American Association of Colleges of Nursing, White Paper of the Role of the Clinical Nurse Leader, 2007, http:// www.aacn.nche.edu/publications/white-papers/cnl/.

[114] Institute of Medicine, To Err is Human: Building a Safer Health System, National Academy Press, Washigton, DC, USA, 1999.

[115] Institute of Medicine, Crossing the Quality Chasm: A New Health System for the 21st Century, National Academy Press, Washigton, DC, USA, 2001.

[116] American Association of Colleges of Nursing, "Facts about the CNL," 2005, http://www.aacn.nche.edu/mediarelations/fact-sheets/accelerated-programs.

[117] T. Wurmser, "Cultivating practice and education partnerships," Nursing Management, vol. 39, no. 3, pp. 44-48, 2008.

[118] D. S. Smith and M. T. Dabbs, "Transforming the care delivery model in preparation for the clinical nurse leader," Journal of Nursing Administration, vol. 37, no. 4, pp. 157-160, 2007. 


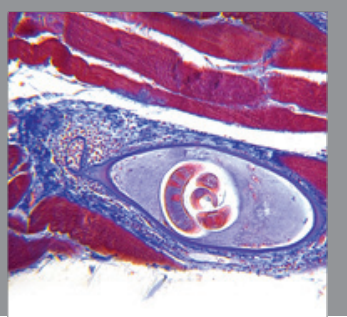

Gastroenterology

Research and Practice
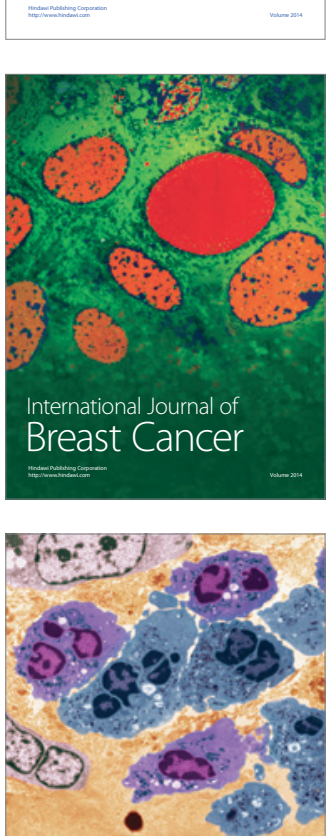

International Journal of Inflammation
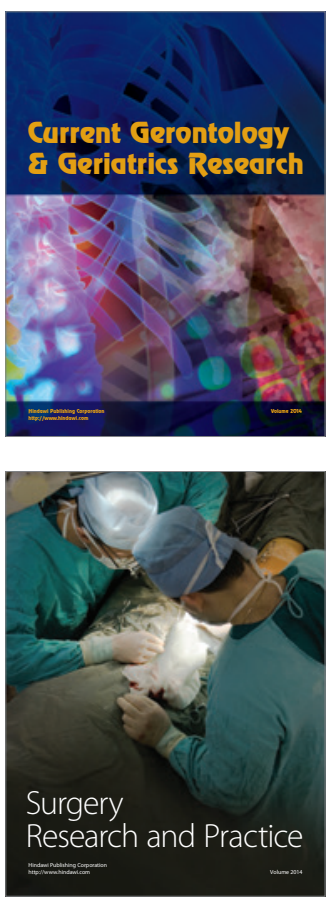
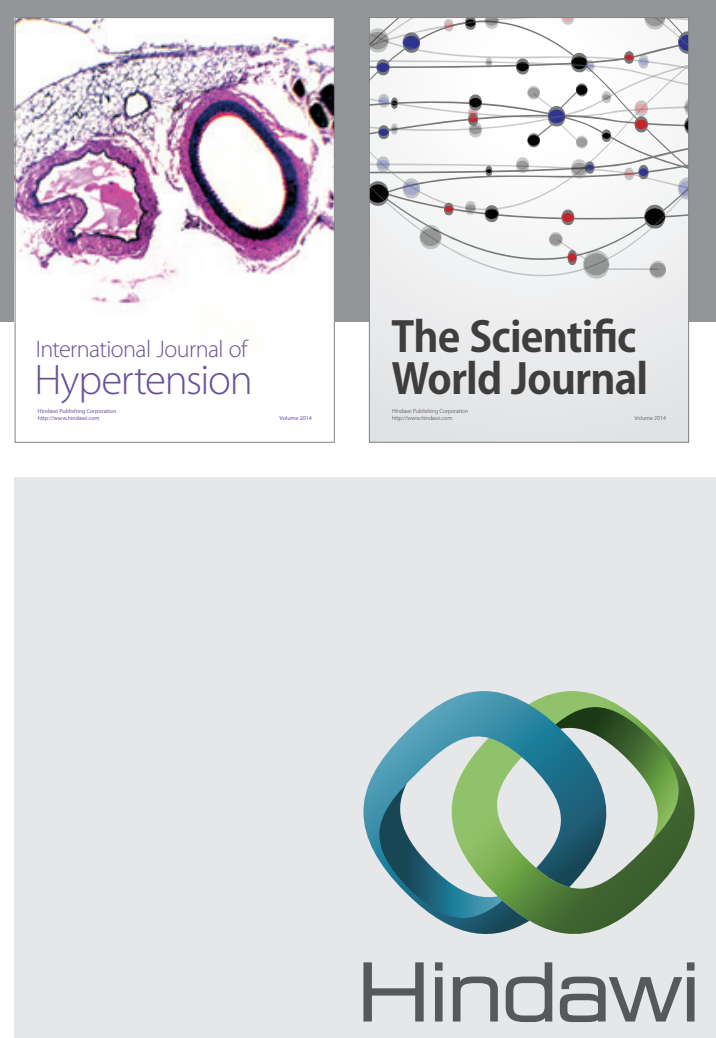

Submit your manuscripts at

http://www.hindawi.com
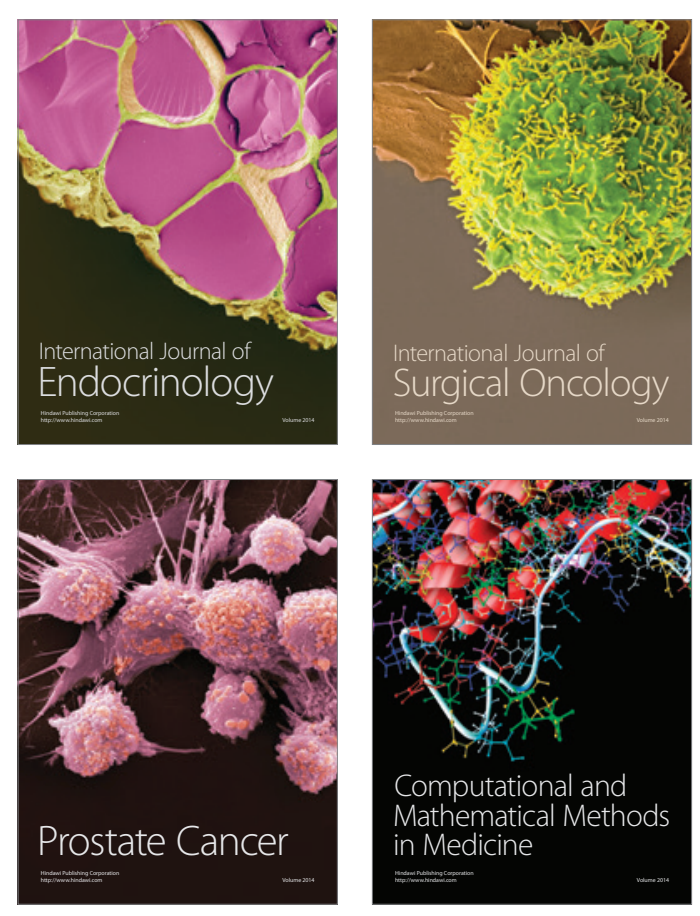
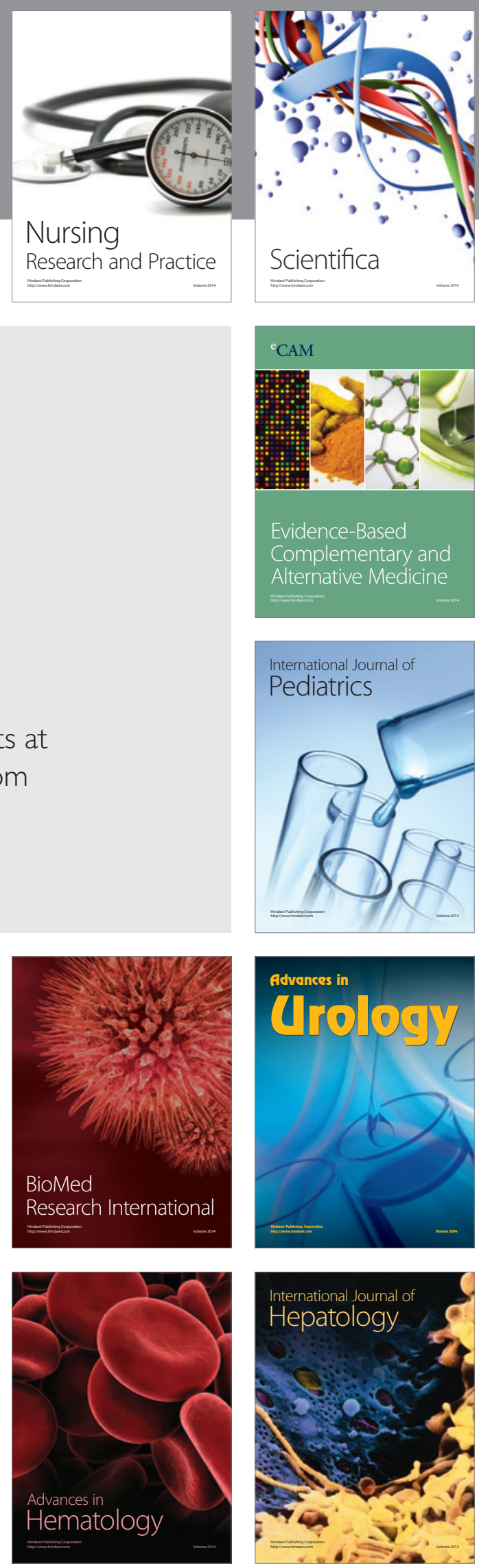